\title{
The Value Changes of Late-Life Divorce In Japan: A Critique of Fumie Kumagai Perspective
}

\author{
Budi Prayogo ${ }^{1}$ and Kurniawaty Iskandar ${ }^{2}$ \\ \{budi.prayoga168@gmail.com ${ }^{1}$, daradwipa@yahoo.com ${ }^{2}$ \} \\ ${ }^{1,2}$ School of Strategic and Global Studies, Universitas Indonesia, Indonesia
}

\begin{abstract}
In the Japanese society, there have been various problems and unique phenomenon from the effects of modernization and industrialization progress. Its starting from decline in fertility rates, marriage postpone, increased rates of elderly, and a late-life divorce. Based on research from journal article by Fumie Kumagai, The phenomenon of an elderly couple's divorce or commonly called Jukunen Rikon is increasing drastically in Japan. Kumagai points out from several reasons in the form of demography, economy, culture, and gender, the most dominant influence of Jukunen Rikon's rise is baby boomers generation which born in 1947-1949 leading to an increasing percetages of elderly people in the 2000s. Criticism of Kumagai from this research is to more explained the increasing of Jukunen Rikon by the concept of male domination in Japan. This patriarchal concept resulted in the wife experiencing fatigue in the marriage relationship and make a decision to get a late-life divorce.

This research uses qualitative method with previous literature research data and library research data which also examines the same theme of the value changes of late-life divorce in Japan. The study data includes other experts such as Makidon and Alexy who also discuss about Jukunen Rikon. By comparing Fumie Kumagai's perspective with the perspective of the other experts, we hope to see a value change of late-life divorce phenomenon in Japan with more comprehensive.
\end{abstract}

Keywords: Late-life Divorce, Values Change, Government Policy, Gender Equality

\section{INTRODUCTION}

Modern Japanese society's view of divorce has changed ever since the end of the second world war. The process of modernization that occurs in Japanese society can not only have a positive impact, but can also have a negative impact on their lives. The welfare of every family in Japan is not always balanced with harmony in marriage and love. Today in Japanese society, marriage is only used as a place to have children and to maintain the image in society. Meanwhile, Divorce is no longer needed to be cried, even divorce celebrations are now become a new trend (Mariko, 2001: 14). 
A long time ago, The Japanese state is still under the influence of a family-oriented tradition that is women are forced to always obey to become housewives and take care of children (Iwai, 2010). Although since the 1990s, women have begun to get support by various legal policies and social views to get more free lives and maintaining their own lives. The progress of modern industrialization that occurs today has a variety of positive and negative impacts on people's lives in various parts of the world, especially for Japan. One of the positive impacts of this modern thought is the beginning to pay attention to gender equality for the welfare of women. The existence of gender equality is increasingly emphasized following the style of the western country. But for Japan this gender equality turned out not to always have a positive impact because of the very strong patriarchal traditions they embraced and instead led to the emergence of various problems for the lives of Japanese people.

With more of single women who are more concerned with their careers, there is so many of them prefer not to get married and postpone their marriages, this is commonly referred to as Bankonka. This phenomenon causes increasingly men in finding married couples more difficult. The individual reasons for women who do not want to get married are divided into two categories. The first group can marry but become unmarried, because there is a change in the perspective of marriage. The second are groups who want to get married but cannot marry because of limitations in economic terms or have not found a partner who has economic degrees in accordance with their expectations (Mariko, 2001: 6).

Various phenomena that are starting to emerge are a big enough problem that it needs handling from the government to overcome them. In addition to the problem of postpone in marriage, the problem that is now becoming a phenomenon that is often faced by Japanese families is the beginning of increasing divorce in old age or after retirement called the Jukunen Rikon.

Jukunen Rikon or late-life divorce is a phenomenon that is currently experiencing a drastic increase in Japanese society. A lot of speculation began to emerge regarding this increase in Jukunen Rikon. One of them is due to the increasing presence of elderly people living in Japan from the results of baby boomers that occurred at the end of World War II. Baby boomers are called the biggest reason for the increase in divorce in old age. The birth of babies that increased in the years 1946-1947 caused the presence of older people more and more in the 2000s. Many women aged 50 years and over who want divorce on the grounds that they never find peace in their marriage (Yvonne P. Makidon, 2003).

The existence of the Law of kouseinkin no bunkatsuseido in April 2007 which supported gender equality in Japan turned out to have a negative impact, so many Japanese wives preferred to divorce when they got older. The wife feels that with their divorce, she will have the freedom of endless household chores and enjoy her old days quietly. However, there was an ambiguity in the pension law in 2007. According to Fumie Kumagai (2014) many wives wished to be able to file a divorce after April 2007 to get half of their husband's retirement salary, but they were disappointed that half of the pension salary was new they can get when their ex-husband and his family agree to it. From the phenomenon of this retired policy, we can take the hypothesis that the increase in divorce in Japan is very much influenced by gender and government policy systems based on patriarchy.

Seeing changes in values that occur in contemporary Japanese society. The author will try to see how the changes in values that occur in this elderly divorce can occur by referring to the theory put forward by Prof. Fumie Kumagai. He is a sociologist who conducts further research on changes in values experienced by contemporary Japanese society.

Fumie Kumagai as a sociologist on Japanese family structures, has the most influential perspective on the divorce of elderly people in Japan. Therefore, the author will try to find out 
what are the most appropriate causes of changes in values that occur in divorce of elderly in Japan seen from the concept of research proposed by Fumie Kumagai. In addition, the author will also criticize and explain the shortcomings and strengths from the perspective of Fumie Kumagai. So from this study, the authors hope that we can see the change in the value of divorce in elderly couples in Japan more comprehensively.

\section{LITERATURE REVIEW}

The literature review in this section comes from several books that discuss the problems of Japanese women in modern times, gender equality and the study of changes in values in Japanese family structures. The literature books that will be discussed in this literature study consist of, the first research book written by Mariko Bandou (2001) with the title "Nihon no Josei Dettabangku", the second is a book study written by Ochiai Emiko (1997) with the title of "The Japanese Family System in Transition", and the third is a textbook research conducted by Lise Vogel (2013) entitled "Marxism and the Oppression of Women: Toward a Unitary Theory". In addition, the author will also add a number of other literature books which are not explained in full in this literature review chapter.

Based on Mariko research (2011), the level of divorce in annual data during the period 1965-2000, the last four decades, as in other developed countries the level of divorce in Japan has increased. In addition, according to the concept of Mariko (2011) also discusses the various social changes that women have in social life in Japan. This change began with women who were more concerned with their careers and began to postpone marriage to not wanting to get married (Bankouka). Until the increasing divorce both in early marriage and in the elderly (Jukunen Rikon). These changes occur due to the modernizing effect of increasing gender equality in Japan (Mariko, 2011: 14).

According to Emiko's (1997) theory and concept, women are still highly discriminated against in the realm of work. In the view of Japanese society, women are always played as housewives who live at home so that it is very difficult for her to work and career. This situation makes most women prefer not to get married and divorce. But other problems faced by divorced women are difficult to meet the financial needs of themselves and their children (Emiko, 1997).

In a recent literature review, Vogel (2013) wrote about the big debate among socialist / Marxist feminist scholars on dual theory of oppression of women, namely the theory of social reproduction and the division of sexually labor. In his theory, Marxist-Socialist Feminism has a goal of restructuring so as to achieve gender equality in society. The capitalism system that gives rise to classes and division of labor including within the family creates gender inequality. In his book, Vogel also adopted the Praxis Marxism theory, namely the theory of awareness of oppressed groups so that women are aware that they are 'disadvantaged' classes. This awareness process is an attempt to arouse the emotional feelings of women so that they will try to rise to change the situation (Marxism in Vogel, 2013).

In addition to the literature study books above, in this thesis research the author also added several sources as consideration for strengthening the data to be studied. The source of the previous study is in the form of articles, journals and previous research theses using the same approach but with different objects or research subjects. The first is the Dissertation Journal study conducted by Yvone P. Makidon (2013) with the title "A Study of Baby Boomers Divorced Women and Their Divorce Experiences". The second is the research of journal articles conducted by Allison Alexy (2011) entitled "Intimate Dependence and its Risk in Neoliberal Japan". The third is the research of journal articles conducted by Hiromi Ono and 
James Sanders (2009) with the title "Divorce In Contemporary Japan and Its Gendered Patterns".

First, in his study, Makidon (2013) interviewed 25 female participants who were known to be the result of baby boomers and chose to divorce from their husbands. 10 of the 25 women claimed they have no peace during their married life. They felt that during the marriage life, the job of being a housewife was very heavy and tiring. Starting from taking care of children, taking care of household work, and taking care of family finances. Their husbands have never helped them at all, even always making their work more tiring by going home late at night, drunk, and forcing them to deal with it harshly. This life lasts protracted until it is difficult for women to live freely (Makidon, 2013).

Furthermore, Alexy (2011) examines how the attitude and treatment of husbands to their wives is the main reason for divorce. When their husbands go home they don't return their wife's greeting (aisatsu). Then, their husbands will ask for beer and call their wives as "mothers". This "Mother" call is the beginning of the breakdown of their marital relationship. The husband only views their wife as a mother to raise and care for their children and indirectly make themselves a substitute for the husband's mother. This is where love relationships have begun to fade and wives have felt themselves misused in the realm of family (Alexy, 2011).

The last, Ono and Sanders (2009) examine how Japan is the country that has the lowest gender equality compared to western industrialization countries. Even so, the existence of divorce in Japan has a significant increase and continues to increase every year. The occurrence of various divorces to protect women began to bloom since the Meiji period (1868). Divorce is said to be the best way for a wife to get freedom from the restraints of their ruling husbands and constant work at home. According to Cornell $(1989 ; 1990)$ divorce in Japan is closely related to gender equality issues. How does this theory explain that the level of gender equality in Japan greatly influences the level of divorce that occurs in society.

In contrast to the concept of the experts above, Fumie Kumagai (2006) in his journal entitled "The Fallacy of Late-Life Divorce in Japan" divides the percentage of divorce rates based on periods in Japan and is known in the last 30 years that the divorce of the elderly increases the highest percentage. The discussion of the phenomenon of elderly divorce was raised in conjunction with the issue of government policy in 2007. It was said in 2007 would be the beginning of a high increase in divorce for the elderly, this was due to several factors, namely the issue of government law concerning the giving of half of the husband's pension to his divorced wife and the existence of many 60-year-old elderly retirees from the baby boomers in 1947 (Kumagai, 2006).

Looking at the literature review and previous studies in the points above, the author will examine the changes in values in modern Japanese society as seen from the phenomenon of divorce in the elderly by using the theory and concept approach proposed by Fumie Kumagai with other experts. By using this theory and concept, it is expected that the writer can analyze and see more comprehensively how Japanese women experience changes in social values in the family so that the phenomenon of divorce in the elderly is increasing in modern times today.

\section{METHODOLOGY}

The kind and type of research used in this thesis are qualitative methods using previous literature research data and library research data or library research. By looking at the data in the previous journal articles regarding divorce in elderly Japanese couples written by Fumie 
Kumagai, the author decided to make Kumagai's research as a reference object in seeing changes in the value of divorce in the elderly that occur in Japanese society today.

According to Creswell (2012), in qualitative research there are four types of data collection techniques, namely observation, interview, documentation, audio-visual, and triangulation techniques. Whereas in this thesis research, the writer will focus more on using data collection techniques with documentation techniques from secondary data.

Based on the research objectives to be achieved, the author will begin the analysis by examining all the data that has been available from various sources, namely documentation and triangulation. By conducting data reduction, the data obtained in the literature are summarized by choosing the main things and are arranged more systematically so that they are easily controlled. In this case the author uses qualitative data analysis, where the data obtained are analyzed by descriptive method by means of inductive thinking, namely research starting from facts that are empirical by learning a process, an invention that occurs, recording, analyzing, interpreting, reporting and draw conclusions from the process.

\section{DISCUSSION}

\subsection{Jukunen Rikon as Fumie Kumagai Perspective}

According to Fumie Kumagai, Jukunen Rikon or divorce for elderly couples who have usually been married for more than 20 years, has become common since the mid-1990s in Japan. There are many speculation was raised by Kumagai regarding the increase in the phenomenon of elderly divorce. In 2006, she wrote a book which argued that there were several reasons for Jukunen Rikon in Japanese society, namely the existence of baby boomers, retired policy in 2007, the emergence of retired husband syndrome, and wife's fatigue in marital relationships. However, in 2014, Kumagai renewed his findings regarding the emergence of the Jukunen Rikon phenomenon into five findings.

Therefore, in this chapter the author will analyze how the findings raised by Kumagai can be closely related to the emergence of an increase in Jukunen Rikon in Japan. The first finding, for the last 30 years the increase in Jukunen Rikon has been very drastic. Secondly, there will be a major change in the Jukunen Rikon case since 2007 which may have been caused by the government policy regarding ambiguous distribution of pensions. Third, this increase in divorce occurred mainly due to baby boomers born between 1947 and 1949. Fourth, the longer the marriages went, the less likely the couple to divorce. The last, the reasons for divorce at the end of life are different from those expressed for divorce in general (Kumagai, 2014: 119137).

Kumagai said that it was only natural that the divorce of the elderly increased in the mid1990s. This happened because of the effects of the baby boomers who walked the 50s. So that more and more elderly population in those years. However, if we look at the changing values and behavior of Japanese people in modern times, is this demographic reason strong enough to prove that this drastic increase in divorce in the elderly is only due to an increase in the population of the elderly population in Japan? 


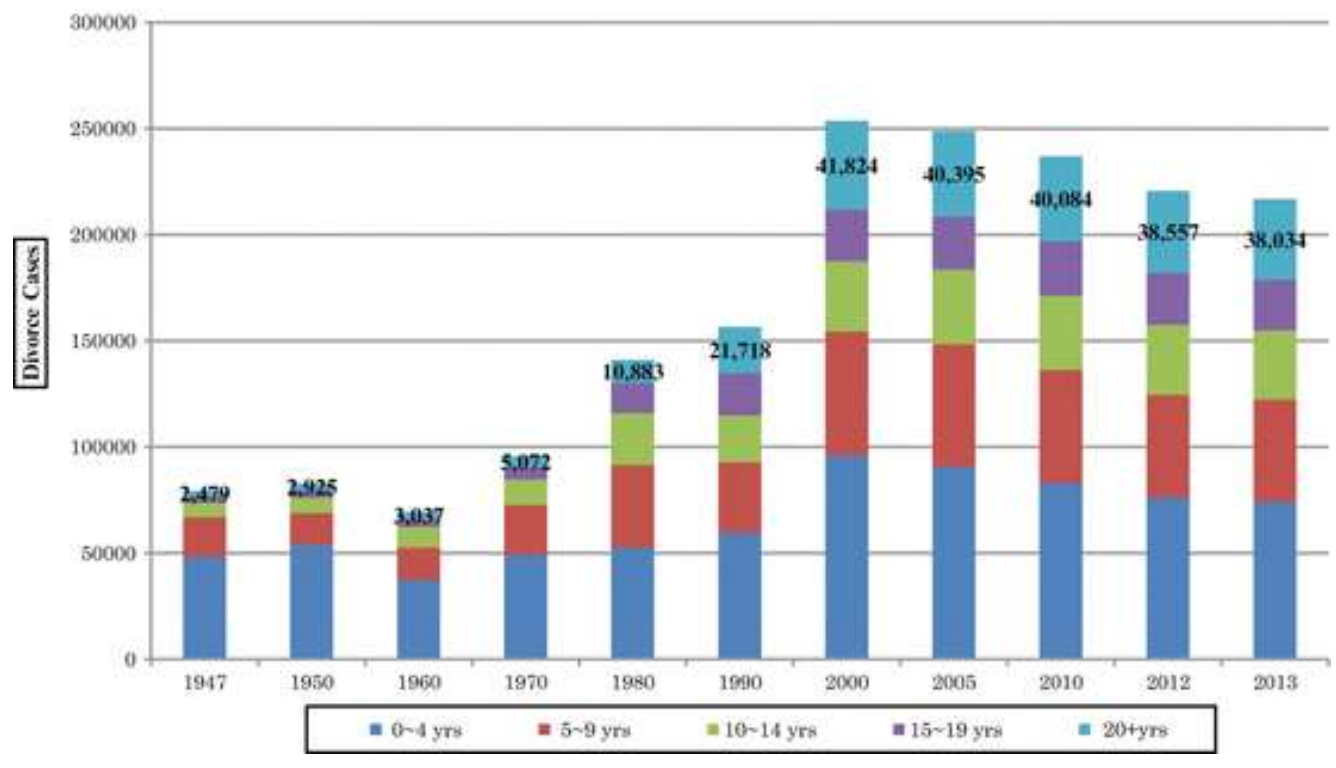

Figure 1. Statistic of Jukunen Rikon in 2013

Source: Fumie Kumagai (2014, chapter 6, hal 119-137)

In graph 4.1 above we can see that divorce cases at the age of 20 years and above have increased in the duration of the last 30 years. This number continues to double every 10 years, starting in 1970 with only around 5,000 divorce cases rising to 10,000 divorce cases in 1980 . Then in 1990 the increase increased again to 20,000 cases and in 2000 this increase rose up to 40,000 cases. Although in the next 10 years the rate of increase in these cases did not rise again, the figure has remained stable to date. Even the increase in divorce at marriage over 20 years is higher than the increase in divorce cases under 20 years.

In addition, according to him the possibility to be able to contribute to the trend of increasing divorce in the long term is the "Renewal Regulation of the Old Age Pension Division" which was proclaimed in 2007 or in Japanese called kouseinkin no bunkatsuseido. Changes to regulations regarding the reform of old-age pension plans were announced on June 5, 2004 and entered into force on April 1, 2007. In contrast to government regulations regarding the distribution of pensions in the 1980s where the pension received by women became one with their husband's pension. In this 2007 policy on retirement pension plan, it is applied to give the wife half the old pension money that is received by her husband, then the wife will get the same pension income as their husband when they divorce

However, this old-age pension policy must be studied carefully. Because in reality, this policy is not as attractive as it appears on the surface. This does not mean that a wife who divorces directly is entitled to receive half of the pension received by her divorced husband. Many conditions need to be done by his wife and husband so that this can be achieved. There are enough schemes that make it difficult for women to only be $50 \%$ more likely for them to get a pension for their ex-husband who will be divorced, even most of them have to feel frustrated at failing to get the money. 
Kumagai also predicted the changes in increasing of late-life divorce due to the demographic factors of the baby boomer effect that occurred in Japan. By looking at the statistics of the growth of the elderly, which is increasing due to the baby boomer factor, then I think that divorce in the elderly will also increase. According to him the striking increase in divorce cases in the elderly is largely due to the population of baby boomers born between 1947 and 1949. Their existence has now entered the stage of life where they have passed 20 years or more of marital life. Most of these baby boomer populations are very difficult to maintain their marriage so that divorce in the elderly is now more than ever before.

Unlike Kumagai's opinion, according to Alexy (2011) being a housewife is not a dream and desire of Japanese women. But they were forced to become housewives due to the demands of the environment and the people who supported it. Although the marriage they run is based on love, but after years of marriage as a housewife, these women begin to regret for the decision they had taken before. Having to prepare dinner every day for her husband is very painful. until many of them experience stress and decide to divorce. Even though there is a sense of love in the marriage, maybe that feeling starts to erode little by little and leaves hatred (Alexy, 2011).

The next Kumagai findings, the longer the time of one's marriage, the harder it will be for them to separate. This happens because the stronger the trust and bond of a couple who is married for a long time. In addition, married couples will also have a strategy that they develop throughout their marriage so that there will be fewer disputes between married couples. Even though there is a ups and downs in marital life, long-married couples have developed effective ways to overcome the difficulties they face (Kumagai, 2014: 133).

Furthermore, the last, the reasons used to divorce in old age seems different compared to divorce in general. That is, many wives in divorce at the end of their lives have a negative attitude towards their husbands after they retire. The wife may feel that her lifestyle has become accustomed to being alone without her husband's presence, being very disturbed when her husband retires and is home every day. This situation makes the wife think it is better to divorce so that her life feels more calm. Many of the wives want divorce in old age, but have very little knowledge about resources for their own financial well-being after they divorce. What awaits them at the end of life is not an easy way to go (Kumagai, 2014: 133).

\subsection{Jukunen Rikon and Changes in values in Japanese society}

In contemporary Japanese society, Japanese society's view of divorce began to change. There is a change in values adopted by Japanese society so divorce is no longer a taboo thing to do. Even divorce is the best way a married couple can have a better life than a married life that they consider unhappy. Divorce that occurs in Japan not only occurs in couples who have not been married for a long time, but this divorce also occurs in the elderly who have retired.

However, we can see that unilateral divorce or arbitration has become more common in recent decades. Nearly $8 \%$ of divorces are now reached by arbitration in the domestic relations court. Another type of divorce, namely divorce through agreement, can only be given when the husband and wife fail to agree to the divorce provisions or in cases where the arbitration is not tried. However, at present divorce with a difficult agreement is rarely done. Courts currently more often unilaterally make divorce decisions and bind partners legally to uphold the provisions. This type of divorce decision can usually be given in cases of infidelity, dangerous neglect, the presence of an unknown one or another partner for at least three years, 
serious mental illness with little chance of recovery, or when the partner has other serious reasons to doubt his worth. continue in marriage (Kumagai, 2014).

According to Makidon (2013), divorce that occurs after years of marriage or Jukunen Rikon may have been done based on the consideration that children are mature enough so that the psychological impact of parental divorce can be minimized. Therefore, Makidon considers a husband-wife who wants to divorce will try to live their unhappy marriage life for their children. However, when their child is older and can live independently. These couples feel that they no longer have dependents in their marriages so that they will be easier to hold a divorce.

Enjoying life after retirement as a partner has not become a lifestyle that is fully appreciated by the Japanese. Most Japanese men who have devoted their lives to working outside the home find it difficult to manage their free time after they retire. And when their husbands retire from work, most Japanese women have formed independent lifestyles that do not include their husbands. The presence of husbands full of unconsciousness at home often has a negative impact on family life (Alexy, 2011).

Alexy (2011) also said that being a housewife is not a dream and desire of Japanese women. But they were forced to become housewives due to the demands of the environment and the people who supported it. Although the marriage they run is based on love, but after years of marriage as a housewife, these women begin to feel sorry for the decision they had taken before. Having to prepare dinner every day for her husband is very painful. until many of them experience stress and decide to divorce. Even though there is a sense of love in the marriage, maybe that feeling starts to erode little by little and leaves hatred (Alexy, 2011).

In the journal Alexy article (2011) there is a strong reason why married couples in Japan experience unhappy marital life. That is due to attitude and calling the name of the husband to their wife. Unmarried couples usually use "you" (anata) to talk to each other, but married couples use this word as "you" or "dear". This word can also be characterized by his wife as the term "full of love" (Smith and Wiswell 1984: 176). In this case, the implication is that most married couples start calling each other "mother" and "father" immediately after marriage, maybe even before having children. They immediately forget the word "dear" (anata) they should use and regard this as an intimate gesture that embarrasses most people.

When a husband has retired, most of them do hobbies or just relax at home without doing anything. Japanese men often do this so that they disrupt their wives who have been at home throughout their marriage life without their husbands. This is often called by most wives to equate their husbands with a pile of wet leaves (you try to sweep them but they just keep quiet there) (Iskandar, 2017: 35).

The majority of divorces in the elderly were initiated by the wives. The increasing frequency of divorces initiated by the wives shows that women have gained increased autonomy in marriage. The patriarchal concept of Male Domination that has been embedded in Japan has made women long their autonomous deficiencies in marriage. So, the main reason they have is their dissatisfaction with traditional gender roles which restrains them in the domestic sphere.

\subsection{Analysis and Criticism of Kumagai Perspective}

In both books and journal articles written by Fumie Kumagai, he always focused on the concept of Japanese families experiencing changes in structure and values in contemporary Japanese society. In addition, in her research from 2006 to 2015 there were at least five main issues raised regarding the discussion of Jukunen Rikon. In her writing, I hope that her 
analysis of the Jukunen Rikon will clarify what seems to be a mistake from previous understanding.

The perspective raised by Kumagai also does not always exist in one place, but also moves from seeing history to the possibility that will occur in the future. In addition, the excess of research conducted by Kumagai is always exposed to the clear and neatly arranged with a variety of authentic evidence in the form of statistical data that supports it. So that readers from all over the world will be forced to understand and not misunderstand the structure of changes in values adopted by Japanese families.

Although Kumagai always conveyed the concept of the theory that her examined clearly using statistical data. However, she was too focused on the existing statistical data so that she did not see the strongest reason for the emergence of Jukunen Rikon in Japanese society. She also compares too many changes that occur widely, so that changes arise due to internal reasons less attention to and discussed in detail. This makes a lot of understanding displayed less on target.

In addition, another disadvantage of Kumagai's theory and concept is that it does not extend the implications of his analysis both in time and place for the global process in each of her books and journal articles. I like to have too broad a perspective and pay little attention to the small things that provide a process for the global influence that she discussed.

Then one thing that is a little less than every book and journal article Kumagai is she always ends every writing with the conclusion of a sudden analysis and burden some one thing. Even so, I continue to provide analysis and insights that are far enough that it increases our understanding of family conditions in Japan in sufficient detail.

\section{CONCLUSION}

The discourse on gender equality continues to emerge in Japan, but the male domination's patriarchal concept that has long been embraced by the Japanese state is still maintained today. this was also reinforced by the emergence of various patriarchal government policies with the guise of public welfare. It is from this concept that women are increasingly confined and difficult to pursue careers freely in this country. The desire and aspiration to realize their career path always collided with government policies and the views of the Japanese people so that they were forced to follow the prescribed path. For this reason some women try to run away by doing various things such as delaying marriage and divorce. Divorce that occurs in Japanese society not only occurs at the general level but also occurs in many marriages that have reached the age of over 20 years called Jukunen Rikon.

According to Fumie Kumagai, in the period 1964-2006 divorce in the elderly increased drastically. I say that from a number of reasons in the form of demography, economics, culture, and gender, the most dominant influence on increasing the Jukunen Rikon is due to the increasing population of the elderly in the 2000s from the results of the baby boomer generation. Criticism of this research is that it is expected that Kumagai can see more of the increase in Jukunen Rikon with more detail towards internal factors and more to assess the process in the occurrence of this matter than just looking at the statistical data that appears on the surface. Examples such as the discussion of the concept of male domination in Japan and the husband's retirement syndrome are troublesome for the wife.

If we compare and review the opinions of the other experts such as Makidon, Hiromi \& James, and Alexy who emphasize gender reasons and patriarchal government policies. There are so many perspectives on Kumagai that we can criticize and prove the truth more clearly. 
From this analysis, this was also reinforced by the concept of ambiguity from the Japanese government regarding the importance of gender equality through higher education and the distribution of wages in companies in a gender way, in reality for women its continues to curb their freedom in society. It is known that culture and patriarchal concepts that are inherent in Japan are the most influential things to Jukunen Rikon. This results making the wife experiencing fatigue in marriage relationships and deciding to divorce in their elderly life.

\section{ACKNOWLEDGEMENT}

This research based on grant scheme of PITTA (Publikasi International Terindeks untuk Tugas Akhir) 2018 or also known as Indexed International Publications for Final Projects toward Universitas Indonesia students. Thank you to Kurniawaty Iskandar as my advisor.

\section{REFERENCES}

[1]. Alexy, Allison. (2011). Intimate Dependence and its Risk in Neoliberal Japan. George Washington University Institute for Ethnographic Research.

[2]. Bandou, Mariko. (2001). Nihon no Josei Dettabangku. Kantor Kabinet dan Arsip Nasional: Tokyo Jepang.

[3]. Emiko, Ochiai. (1997). The Japanese Familiy System in Transition. Japan: LTCB International Library Foundation, Tokyo 100.

[4]. Hachiro, Iwai . (2010) " Changing Patterns of the Course of Women's Lives in Japan's Lost Decade: An Analysis of the Work History of the Second Generation Baby Boomers " Journal of Intimate and Public Spheres p55-71

[5]. Iskandar, Kurniawaty. (2018). Aging Society in Japan; Focusing on The Life After Retirement in a Sub Urban Area. Depok: Universitas Indonesia

[6]. Japan Statistics Bureau. (2015). Japan's elderly population. Diakses pada 28 Juni 2018 dari: https://www.theatlas.com/charts/rkBlpp32

[7]. Kawashima, Takeyoshi dan Kurt Steiner. (1960). Modernization and Divorce Rate Trends in Japan. Chicago: The University of Chicago Press

[8]. Kumagai, Fumie. (1996). Unmasking Japan Today: The Impact Of Traditional Values On Modern Japanese Society ( Praeger, 1996) (ISBN0-275-95144-8).

[9]. Kumagai, Fumie. (2006). The Fallacy of Late-Life Divorce in Japan. Springer Publishing Company

[10]. Kumagai, Fumie. (2008). Families In Japan: Changes, Continuities, And Regional. Lanham, MD: University Press of America , 2008 (190 pp).

[11]. Kumagai, Fumie. (2010). Forty Years of Family Change in Japan: A Society Experiencing Population Aging and Declining Fertility. Journal of Comparative Family Studies; Summer 2010; 41, 4; ProQuest pg. 581

[12]. Kumagai, Fumie. (2014). Family Issues on Marriage, Divorce, and Older Adults in Japan. Springer: Singapore. Diakses pada 20 Juni 2018 dari: https://link.springer.com/chapter/10.1007/978-981-287-185-5_6

[13]. Makidon, Yvone P. (2013). A Study of Baby Boomer Divorced Women and Their Divorce Experiences. Michigan State University.

[14]. Ministry of Health, Labour and Welfare. (31 maret 2008). Overview of the Pension System in Japan. Diakses pada 20 Juni 2018 dari: http://www.mhlw.go.jp/english/org/policy/dl/p36-37p2.pdf 
[15]. Ministry of Health and Welfare. (1983). Kekkon ni Kansuru Jinkogakuteki Chosa, (Penelitian Demografi Pernikahan), Dalam (Emiko, 1997).

[16]. Munson, M.I and P.D. Sutton, 2005. Table A. Births, marriages, divorces, and deaths: Provisional data for 2004. National Vital Statistics Reports 53 (21): 1-7. (Hyattsville, MD: National Center for Health Statistics.) Diakses pada tanggal 28 Juni 2018 dari: http://www.cdc.gov/nchs/data/nvsr/nvsr53/nvsr53_21.pdf

[17]. Ono, Hiromi dan James Sanders. (2009). Divorce In Contemporary Japan and Its Gendered Patterns. Wasington: Wasington State University

[18]. Rebick, Marcus \& Ayumi Takenaka. (2006). The Changing Japanese Family. London: Routledge.

[19]. Rosenberger, Nancy. (1991). "Gender and the Japanese State: Pension Benefits Creating Difference."Anthropological Quarterly 64(4): 1 78-1 93. Dalam (Alexy, 2011)

[20]. Sigeto, Tanaka. (2013). A Quantitative Picture of Contemporary Japanese Families. Japan: Tohoku University Press

[21]. [Tanaka 2008b] Tanaka Sigeto, (2008), “Career, Family, and Economic Risks,”中井美 樹。、杉野勇編『2005年SSM調査シリーズ9：ライフコース.ライフスタイルか ら見た社会階層』2005年SSM調査研究会、21-33

[22]. Statistics and Information Department, Minister's Secretariat, Ministry of Health and Welfare. (2000). Jinko Dotai Toukei 100-nenn no Ayumi [100 years of vital statistics in Japan: 1899-1998]. Tokyo: Govern-ment Printing Office. Diakses pada 10 Maret 2006 dari: http:// www1.mhlw.go.jp/toukei/kjd100_8/index.html. Dalam (Kumagai 2006)

[23]. Statistics Bureau, Ministry of Health, Labor, and Welfare. (2004). Heisei 16-nen Jinko Doutai Toukei Geppo Nenkei no Gaiyo [Vital statistics of 2004-Summaries]. Diakses $\begin{array}{llll}\text { pada } & \text { Maret } & 2006 & \text { dari: }\end{array}$ http://www.mhlw.go.jp/toukei/saikin/hw/jinkou/geppo/nengai04/ Dalam (Kumagai 2006)

[24]. Statistics Bureau, Ministry of Health, Labor and Welfare. (2005). Heisei 17-nendo Jinko Doutai Toukei no Nenkann Suikei [Preliminary re-port of the vital statistics for the year 2005]. Diakses pada 10 Maret 2006 dari: http://www.mhlw.go.jp/toukei/saikin/hw/jinkou/suikei 05/index.html. Dalam (Kumagai 2006)

[25]. Vogel, Lise. (2013). Marxism and the Oppression of Women: Toward a Unitary Theory. Brill. Koninklijke Brill NV incorporates the imprints Brill, Global Oriental, Hotei Publishing, IDC Publishers and Martinus Nijhoff Publishers. 